\title{
The Extent of the Scope of Punishment
}

\author{
By Itumeleng Lephale*
}

\begin{abstract}
One of the reasons for imprisonment is to provide offenders an opportunity to reform. The aim is thus to offer offenders a second chance. This practically means that upon release from custody offenders should be free to pursue any possible means to lead a constructive life. Thus the scope of punishment should not go beyond the bounds of prison walls. To take the scope of punishment beyond imprisonment would defeat the very purpose rehabilitation. For those who have been imprisoned, the rebuilding of their lives will include an opportunity of employment. Many employers are, however, hesitant to employ ex-convicts. This hesitance to employ ex-convicts basically turns into the marginalisation and exclusion of ex-convicts into the labour mainstream. This sort of exclusion is seen by many as a second punishment, which falls foul to the idea of reincorporation of ex-convict into the community. This paper will impugn the view that ex-convicts cannot be trusted with employment and thus should be side-lined in the labour mainstream.
\end{abstract}

\section{Introduction}

The writing of this dissertation was triggered by the high number of people with previous convictions whom I had observed during my growing-up stages. Many of these people are from townships in general but more in particular the township of Soshanguve where I live. It is in this township that an interest about this topic developed. I felt a need to intervene by way of expressing their heartfelt concerns in writing so that at least they can be re-integrated into the communities in which they once lived and hopefully to enable them to participate in the economic affairs of their country.

Most ex-convicts are jobless and when one inquires as to why they are not working, then one discovers that it is because of these previous convictions that these people are unable to secure jobs notwithstanding the fact that most exconvicts are academically qualified, skilled or studying towards formal qualifications. ${ }^{2}$ To aggravate matters it can be argued that these people have

\footnotetext{
${ }^{*}$ LLB (UNISA). The author is an LLM Candidate and a research assistant at the department of criminal and procedural law at the University of South Africa (UNISA).

${ }^{2}$ According to Dodds Daily News 30 May 2013, Minister Sbu Ndebele during his address on prisoner rehabilitation had this to say, "from April, it was compulsory for every inmate without a qualification equivalent to Grade 9 to complete adult education and training levels 1 to 4 and 10393 were registered for this. Offenders were also being trained as literacy facilitators to teach their functionally and totally illiterate fellow inmates to read, write and study. There were 1413 prisoners registered for the former matric mid-year examinations and 2012 for National Senior Certificate exams. In the past financial year, 1049 were studying towards post-matric qualifications, 3525 towards further education and training college programmes including electrical engineering, civil engineering, mechanical engineering and marketing, and 4188 towards skills- development programmes including basic business skills training and entrepreneurship".
} 
paid their dues to the society by serving their sentences in prison. Questioning these people about circumstances which led them to commit crimes revealed that many were convicted of minor crimes which were committed during the teenage stage. The question that kept on lingering in my mind was where is the sense of justice? Where is the fairness and equality which should exist in the new constitutional democracy that South Africa is supposed to be?

It is heart-breaking to notice that people are still being punished for mistakes which were committed decades if not centuries ago. People are not aware of the long lasting consequences of their actions which at times are prejudicial to the immediate family members.

\section{Discrimination in the Workplace based on Previous Convictions}

According to the general principles of Criminal law, ${ }^{1}$ the purpose of punishment is to amongst other to prevent, deter, and reform. Punishment is justified because it is X's just desert. Apparently punishment is the payment of the account which, because of the commission of the crime, $x$ owes to society. ${ }^{2}$ According to this principle, a logical and reasonable inference can be drawn that once X commits a crime, gets convicted and sentenced, when he is released out of jail after the expiry of his sentence, then $\mathrm{x}$ must start his life on a clean slate. ${ }^{3}$ When opportunities are denied to ex-convicts on the basis of their criminal records, it means ex-convicts' punishment extent beyond what he deserves and in actual fact it's a life sentence. Naude ${ }^{4}$ opines as follows "The effect of a criminal record is that the punishment for the crime committed lasts much longer than the sentence imposed by the court.

It is a basic human right guaranteed by the Constitution ${ }^{5}$ that no person shall be sentenced twice for an offence which punishment has already been meted out. This is essentially tantamount to the double jeopardy principle which protects people from being tried and sentenced twice for the same offence. This particular state of affairs has led to valid questions being asked but with no answers provided. Durham III $^{6}$ asked the following question "How it is possible that a desert based system is able to utilise already punished behaviour as the basis for increases in the severity of sentences for new conviction"?

Although Durham III was asking the question with regard to the role of previous convictions during sentencing stage, this question is still relevant in this topic. Durham III' $s$ question was amplified by the following remarks made by Chatterton "No person should be sentenced for offences which they

\footnotetext{
${ }^{1}$ Snyman (2008) 11

${ }^{2}$ Snyman (2008) 11.

${ }^{3}$ Love (2002) 1705

${ }^{4}$ Naude (2002) 287.

${ }^{5}$ S 35(3) m Constitution of Republic of South Africa Act, 1996.

${ }^{6}$ Durham (1987) 615.

${ }^{7}$ Chatterton (1984) 7.
} 
have committed in the past and for which they have already punished".(Emphasis added)

This is in contradiction to the principle of proportionality which emphasis the proportionality between the crime committed and the punishment meted out. When punishment exceeds the degree of harm caused, then the justice system becomes unfair and exceeds the bounds of what is moderate. This is tantamount to life sentence. Von Hirsch and Ashworth ${ }^{1}$ observe that in a desert based system for sentencing, the severity of punishments should be fairly proportionate to the seriousness of criminal offence."

Whilst serving their respective sentences, convicts embark on a number of both formal and informal educations so as to reform them and prepare them to be reintegrated back into society with long life skills to fend for themselves, their families and the very same communities which they wronged and which they were removed from. ${ }^{2}$ One of the participants in Mutingh's research report ${ }^{3}$ report ${ }^{3}$ was quoted as saying "I went to school in prison and achieved a lot". Reintegration goes hand in hand with rehabilitation which is the emphasis of government in general as evidenced by the number of addresses by a number of government officials during conferences or some gathering of other nature, more specially the white Paper on corrections of 2005.

Some if not all of them acquire these formal and informal educations through the help of a number of government financial schemes. Sometimes this financial assistance comes in the form of bursaries and others in the form of loans which have to be repaid (Emphasis added) later on after successfully securing employment. Because of the criminal record that remains on the ex-

\footnotetext{
${ }^{1}$ Von Hirsch \& Ashworth (2005) 62.

${ }^{2}$ Regional director for correctional services in Limpopo, Mpumalanga and North West, Alfred Tsetsane had this to say while addressing a regional conference on the rehabilitation of offenders at the University of Venda in Thohoyandou" ${ }^{2}$; "South Africa needs alternative solutions to help rehabilitate offenders, says regional director for Correctional Services in Limpopo, Mpumalanga and North West, Alfred Tsetsane. He was addressing a regional consultative conference on the rehabilitation of offenders at the University of Venda (Univen) in Thohoyandou on Monday. "Offenders come from communities and they will return to their communities one day. It means the community and all its organisations must assist the department in its efforts to rehabilitate offenders and to reintegrate them back into society," said Tetsane. He said the department was in the process of developing unique rehabilitation programmes in partnership with Univen. "The programmes will help to change the life of offenders so that they can have a meaningful life as soon as they are released," said Tsetsane. More than 300 delegates from civil society, Univen and the University of Limpopo attended the event. He said community organisations could offer spiritual care programmes and training to offenders. "One of the biggest problems facing ex-offenders is the stigma associated with having been an offender. The fact is that if they are not accepted back into society and provided with opportunities to participate in the economy and community life, chances are they may revert to crime," added Tsetsane". http://metro.co.uk/2013/01/29/disclosing-previous-convicti ons-to-employers-human-rights-breach-court-rules-3371483/ (accessed 07/04/2014); according to a quote extracted from a forum discussion "A prisoner might reform and get an education but fail to get a job just because of a criminal record, in such instances he might reconsider crime as a means of making a living found at http://mybroadband.co.za/vb/showthread.php/ 50068-DA-rejects-scrapping-of-criminal-records (accessed 05/05/2014).

${ }^{3}$ Muntingh (2011) 4.
} 
convicts, they become marginalised ${ }^{1}$ and unfairly discriminated against because they once wronged the society, notwithstanding the fact that they have also paid their debts in full to the society. In this regard Love ${ }^{2}$ puts it as follows "The effect of a criminal record is that it becomes a debt to society that cannot be re-paid."

Lately there have been some riots taking place countrywide by students of universities because of allegations that government financial aid scheme which issue out bursaries and loans to students was bankrupt. Various factors were mentioned which bankrupted the scheme. One of the biggest contributing factors is that bursaries are issued out to convicts who want to pursue whichever career they hearts desires. After successful completion of their studies and their release, they encounter challenges which hinder them when they apply for jobs. Their applications are not considered and ultimately are not hired due to the fact that they have previous convictions and as such are unable to repay back what has been loaned to them notwithstanding the fact that they are qualified to do such work.

The current existing state of affairs is contrary to the objectives and mission of the White paper on corrections of 2005, which describes the responsibility of the Department of Correctional Services, as first and foremost to correct offending behaviour, in a secure, safe and humane environment, in order to facilitate the achievement of rehabilitation, and avoidance of recidivism. ${ }^{3}$ This is in accordance with the Mission ${ }^{4}$ of the department of Correctional service developed in 2002 which reads as follows:

"Placing rehabilitation at the centre of all Departmental activities in partnerships with external stakeholders, through:

- The integrated application and direction of all Departmental resources to focus on the correction of offending behaviour, the promotion of social responsibility and the overall development of the person under correction.

- The cost-effective provision of correctional facilities that will promote security, correction, care and development services within an enabling human rights environment.

- Progressive and ethical management and staff practices within which every correctional official performs an effective correcting and encouraging role."

\footnotetext{
${ }^{1}$ Muntingh (2011) 4. Muntigh shares the same sentiments as opines as follows "It is this lasting effect that ex-offenders and ex-prisoners often experience as being exclusionary and marginalising; Golden Miles Bhudu, leader of the SA Prisonner's Organisation for Human Rights once planned to organise a campaign to mobilse government and NGOS to do away "stigmatising ex-offenderss with a criminal tag" and give them jobs. His attempts were met with DA's with fierce challenge against the blanket scrapping of criminal records of exoffenders

${ }^{2}$ Love (2002) 1705.

${ }^{3}$ Correction Service "White Paper Discusion of 2005 at 4.1; Mutingh (2005) 4.

${ }^{4}$ Correction Service "White Paper Discusion of 2005.
} 
Furthermore one of the elements of rehabilitation as defined in the white paper ${ }^{1}$ is the Empowerment with life-skills and other skills followed by holistic sentence planning process that engages the offenders at all levels-social, moral, spiritual, physical, work, educational/intellectual and mental (Emphasis added).

One of the biggest challenges if not a misconception is that ex-offenders face, apart from running the risk of taking previous convictions by presiding officers into consideration for the purpose of sentencing, is the misconception that ex-convicts are not suitable for employment. That the employer cannot trust ex-offenders with jobs, that ex-offender if hired will be a liability to the employer and not a valuable asset. That ex-convict will chase away the employer's clients if clients are to establish the employer has hired ex-convicts in its company. ${ }^{2}$ Muntingh ${ }^{3}$ expresses it as follows "Having a criminal record can have serious implications for an individual's prospects of finding employment".

Discrimination was and is still rife in South Africa, hence the enactment of the Employment Equity $\mathrm{Act}^{4}$ in 1998 followed by the Promotion of Equality and Prevention of Unfair discrimination $\mathrm{Act}^{5}$ in 2000. These two Acts have one thing in common with a slight difference. The main objective of these Acts is to eliminate ${ }^{6}$ and prohibit all sorts of discrimination, with one Act $^{7}$ targeting discrimination in the employment sector and the other $\mathrm{Act}^{8}$ focusing on discrimination generally. Furthermore the two Acts bolsters section 9 which is one of the firmly entrenched human rights in the Constitution and it reads as follows:

1. Everyone is equal before the law and has the right to equal protection and benefit of the law.

2. Equality includes the full and equal enjoyment of all rights and freedoms, to promote the achievement of equality, legislative and other measures designed to protect or advance persons, or categories of persons, disadvantaged by unfair discrimination may be taken.

3. The state may not unfairly discriminate directly or indirectly against anyone on one or more grounds, including race, gender, sex, pregnancy, marital status, ethnic or social origin, colour, sexual orientation, age, disability, religion, conscience, belief, culture, language and birth.

4. No person may unfairly discriminate directly or indirectly against anyone on one or more grounds in terms of subsection (3). National legislation must be enacted to prevent or prohibit unfair discrimination.

\footnotetext{
${ }^{1}$ Correction Service "White Paper Discusion of 2005 at 4.2.2.

${ }^{2}$ Muntingh (2011) 5

${ }^{3}$ Muntingh (2011) 4.

${ }^{4} 55$ of 1998

54 of 2000

${ }^{6}$ S 6(1) of Employment Equity Act 55 of 1998; McGregor et al (2014)59.

755 of 1998

${ }^{8} 4$ of 2000
} 
5. Discrimination on one or more of the grounds listed in subsection

(3) is unfair unless it is established that the discrimination is fair".

The wording of s $9^{1}$ is clear as to who is entitled to the benefits of the law including equality and protection. Even the treatment should be the same. When you have a criminal record, you won't be deemed to be fit and proper person to be a police official however, there have been a diagnosis that almost one thousand five hundred SA police official have previous convictions but still are under the employ of the SAPS with full pay, whereas others are denied that opportunity because of previous convictions. Furthermore these police official are occupying major positions in the SAPS. ${ }^{2}$

S 17CA (1) of the South African Police Service $\mathrm{Act}^{3}$ provides that "The minister, with the concurrence of cabinet, shall appoint a person who is-

(a) A South African citizen; and

(b) A fit and proper person (Emphasis added)

Supplementary to the above, S $36^{4}$ states that "A member of the SAPS who is convicted of an offence and sentenced to a term of imprisonment without the option of a fine shall be regulation 11 (1) (a) (xiii) ${ }^{5}$ which states that "A person who applies to be appointed as a member must have no previous

\footnotetext{
${ }^{1}$ Constitution of Republic of South Africa Act, 1996

${ }^{2}$ http://www.news24.com/SouthAfrica/News/1-448-cops-have-criminal-records-20130814
} where it was reported that several high-ranking police officials are on a list of officers with criminal records, Parliament's police portfolio committee heard on Wednesday. An audit, which only covered the period prior to January 2010, found 1448 officers had criminal offences, SA Police Service (SAPS) acting deputy national commissioner for human resource development Nkrumah Mazibuko told MPs. The audit was conducted to find out how many officers with criminal records remained in the service's employ. MPs shook their heads in disbelief after Mazibuko was pushed to list the ranks of the convicted officers. They included a major general, 10 brigadiers, 21 colonels, 10 majors, 43 lieutenant colonels, 163 captains, 84 lieutenants, 716 warrant officers, 267 sergeants, 129 constables, and two personnel officers. Most of the officers were convicted after joining the service, and none had been dismissed as yet. "These people are subjected to disciplinary process and then they take the matter up on appeal, and we get an order to reinstate the person," Mazibuko said. Police members convicted and jailed were automatically fired. "If that person appeals the sentence... and he gets the sentence reduced maybe to a suspended one by a criminal court, then in terms of our own [police] act such a person is entitled to apply for reinstatement." ; According to Hosken, Times Live 14 June 2013, Crime intelligence officer Captain Morris Tshabalala tries to avoid photographers after appearing in the Sasolburg Magistrate's Court in connection with a cash-intransit heist. This is a man who is occupying the highest position in the South African Police Service. Interesting enough, the Times can reveal that Tshabalala was convicted of armed robbery in the Pretoria Magistrate's Court in 1994 and sentenced to 10 years' imprisonment. The court ordered he be declared unfit to be in possession of a firearm. Tshabalala joined the South African Police Service in 2002. http://www.timeslive.co.za/thetimes/2013/06/14/captainkgb---witnesses-in-peril.

${ }^{3} 68$ of 1995

${ }^{4}$ South African Police Service Act 68 of 1995

${ }^{5}$ Proclamation R 1599 Government Gazette 24194 of 27 December 2002 
convictions and such person shall allow his or her fingerprints to be taken and allow background enquiries to be made (Emphasis added).

$\mathrm{S} 2 \mathrm{~A}$ of National Strategic Intelligence Amendment Act ${ }^{1}$ provides for the security screening investigations of people applying for a job in it. S 2A (5) provides as follows "The relevant members of the National Intelligence Structures may, in the prescribed manner, gather information relating to-

(a) Criminal records (Emphasis added);

(b) Financial records;

(c) Personal information; or

(d) Any other information which is relevant to determine the security clearance of a person:

Furthermore the fit and proper person requirement has been reiterated in a number of Acts for the purpose of ascertaining suitability of employees. S 10 of the Public Service $\mathrm{Act}^{2}$ states as follows:

(1) No person shall be appointed permanently or be transferred and appointed permanently under section 15 (1), whether on probation or not, to any post in the A or B division unless he or she-

(a) Is a South African citizen;

(b) Is of good character; and (Emphasis added)

(c) In so far as his or her condition of health is concerned, complies with such requirements as may be prescribed

Furthermore the Public Service Commission Research Report ${ }^{3}$ provides that when bringing a new employee on board, the Public Service assesses competence, skills and whether the person is of good character, but must also assess the potential risks that such person poses to the institution by indicating whether they have a criminal record (Emphasis added). The seeming intention with such disclosure is not necessarily to ban employment of people with a criminal record, but for the prospective employer to assess the potential impact this may have on the job requirement and on the organisation as a whole.

The Public Service $\mathrm{Act}^{4}$ is supplemented by the white paper on Human Resources Management in the public service which provides in chapter 5 that "One of the minimum entry requirements for employment in the Public Service is Good Character." Furthermore it provides that "Applicants for employment should be of good character, law abiding and prepared to conform to the high standards required by the Code of Conduct for Public Servants. It is essential to protect the public interest. Potential employees may therefore be required to provide information about past convictions or misdemeanours which could have a bearing on their suitability for employment in the Public Service

${ }^{1} 67$ of 2002

${ }^{2} 103$ of 1994

${ }^{3}$ Public Service Commission (2009) 1

${ }^{4} 103$ of 1994 
(Emphasis added). However, such incidents will not necessarily be a bar to employment, if it can be demonstrated that the nature of the incident poses no threat to the public interest, or the incident was sufficiently long ago, and the person's subsequent behaviour indicates that he or she is now rehabilitated".

The abovementioned wording of the White Paper evidently points to the fact that the information about past convictions and misdemeanours have prejudicial elements which will deny a job applicant with a previous conviction a job opportunity unless the job applicant show cause reasons in his favour which will secure a job for him, but in the absence of good reasons and despite proper qualifications he or she will not get the job.

One of the interesting Act to note is the Employment of educators $\mathrm{Act}^{1}$ which does not address the question of people with criminal records. However, the Public Service Commission report makes mention of the fact that "In the event that an educator was appointed in a post on the grounds pf misrepresentation (e.g if an educator did not disclose that he/she has a criminal record), the employer may in terms of section 11 of the Employment of educators Act 76 of 1998 discharge such a person on account of misconduct. In $D u$ plessis $v$ Department of Correctional Services ${ }^{2}$ The applicant, then chairperson of a parole board, was dismissed for allegedly failing to disclose his criminal record when he applied for the post (Emphasis added). He claimed that he had paid an admission of guilt when he was charged with assault several years before, and had not realised that that constituted a conviction. The applicant claimed that the dismissal was procedurally unfair because he had not been invited to attend a disciplinary hearing. The question is what would have happened had the previous conviction been disclosed? It seems as if disclosure of previous conviction would have played a detrimental role in denying the applicant a job opportunity.

The above -mentioned case is cemented by the matter of Masenya $\mathrm{v}$ Fidelity springbok Services ${ }^{3}$ where the applicant, a security officer, was suspended from work because of the discovery of his previous convictions relating to murder, unlawful use of firearm, assault and theft. What exacerbated the matter what dishonesty on the part of the applicant for failing to disclose those previous convictions.

The situation has escalated even further to such an extent that acquittals, withdrawals and discharge comes into the fore for the purpose of security clearance. This has recently emerged when justice minister Jeff Radebe called for the resignation of the newly appointed National Director of Public Prosecution Mxolisi Nxazana within a month of his appointment. The main reason if not allegations for his removal is that he failed to disclosed that he was once acquitted of murder some decades ago. ${ }^{4}$

This is a list of some of the government departments which requires a job applicant to be of good character or rather to be fit and proper person to be

\footnotetext{
${ }^{1} 76$ of 1998

2 PSGA 787-05/06

${ }^{3}$ GAJB 33462-05

${ }^{4}$ News 24 2014-06-01.
} 
appointed. However, the list is not exhaustive. But given the strict requirements of these Acts, it's highly challenging for ex-convicts if not impossible to secure a decent job.

Lastly in terms of s 15 (1) (a) of the Attorneys Act $^{1}$ unless cause to the contrary to its satisfaction is shown, the court shall on application in accordance with this Act, admit and enrol any person as an attorney if such person, in the discretion of the court, is a fit and proper person to be so admitted and enrolled (Emphasis added). Fit and proper person has not been defined in the $\mathrm{Act}^{2}$, however, according to case law, ${ }^{3}$ a person with a criminal is not a fit and proper person to practice law and as such will not be admitted to practice law. ${ }^{4}$

The discrimination against ex-convicts manifests itself from both government departments and private companies. A prospective government job seeker has to fill in a form called Z83. This form is used as an application form by all the government departments to assist in selecting prospective job seekers who meet the requirements of a particular post. This form is used to identify candidates to be interviewed since obviously not all the applicants can be interviewed. One of the most interesting features of this Z83 form is selection B dealing with personal information.

Amongst the questions asked in the personal information that is required in terms of Z83 is whether you have ever been convicted of a criminal offence (Emphasis added) or been dismissed from employment. According to the special notes appearing on this form all information will be treated with the strictest confidentiality and will not be disclosed or used for any other purpose than to assess the suitability of a person, except in so far as it may be required by the law. Furthermore the information is accordingly required to enable the department to comply with the Employment Equity Act. ${ }^{5}$ In essence this clause in the Z83 form forces the prospective job seekers to disclose their previous convictions. In UK the Court of Appeal has ruled that "having to disclose previous convictions to potential employers is a breach of an individual's human rights." 6

\footnotetext{
${ }^{1} 53$ of 1979.

${ }^{2}$ Attorneys Act 53 of 1979.

${ }^{3}$ Prince v President, Cape Law Society 2002 (2) SA 794 (CC); In Re Ngwenya v Society of Advocates, Pretoria and Another 2006 (2) SA 87 (W).

${ }^{4}$ Slabbert (2011) 210

${ }^{5} 55$ of 1998

${ }^{6}$ http://metro.co.uk/2013/01/29/disclosing-previous-convictions-to-employers-human-rights-
} breach-court-rules-3371483/. This case involved a 21 year old man who was forced to disclose a police warning over two stolen bikes when he was at a job interview and to a university. During an interview with Radio 5 Live, Mike Pemberton, the solicitor who represented the 21 myear old boy remarked as follows "This is a case where human rights equal common sense. You can't argue that something you did when you were 11-years old will blight you for the rest of your life." disclose previous convictions to potential employers is a breach of an individual's human rights; see also The Rehabilitation of Offenders Act 1974; $R$ (on the applications of $P$ and A) v Secretary of State for Justice \& Ors [2016] EWHC 89 (Admin); R (L) v Commissioner for the Metropolis [2010] 1 AC 410. [2014] UKSC 35 (On appeal from: [2013] EWCA Civ 25)? 
This form with its discriminatory clause prevents ex-convicts to apply for jobs, subjectively ex-convicts don't even attempt to apply for jobs, because they have pre-judged themselves and thus disqualified themselves based on the rule that if you have a previous conviction and a period of ten years has not lapsed, then chances of securing a decent and well-paying job are slim. "I made many job applications but I can't say anything about a criminal record in these applications. It is only when you get to the interview that you try and convince them that you are able to do the job but they don't want to listen. As soon as the [criminal] record comes out, you know it is over."1 The special notes appearing on the $\mathrm{Z} 83$ form that the information provided will be treated confidentially and is only there to help governments department assess the suitability of candidates is just a denial of jobs to ex-convicts under the disguise of some lawful excuse.

This assertion is supported by the fact that in 2009 the Public Service Commission undertook a published research, entitled "Management of job applicants with a criminal record in the public service." This report came as a result of an acknowledgement on the part of government of its selecting staff member's lack of awareness of their responsibilities in managing the appointment of persons with criminal records. One of the findings of the commission and a major concern to the Public service commission is that a large number of departments do not conduct any pre-employment screening at all.

However, the good news in that a substantial number of people with criminal records have been employed permanently as found by the public commission report. ${ }^{2}$ This is a positive step by government in advancing pure basic human rights and providing the much needed guideline on how to manage job applicant with criminal records unlike to disown ex-convicts and deny them an opportunity to participate in the economic affairs of their country.

Ex-convicts are still human beings ${ }^{3}$ despite their bad character and as such still entitled to all the Constitutional rights and benefits which accrue to all human beings. No previous deeds or actions must deprive ex-convicts of all their entitlements. The Court in Sauve $v$ Canada $^{4}$ (Chief Electoral Officer) expressed its view as follows:

"When the façade and rhetoric is stripped away, little is left of the government's claim about punishment other than that criminals are people who have broken society's norms and may therefore be denounced and

\footnotetext{
${ }^{1}$ These are the words quoted by one participant extracted from Muntingh (2011) 4.

${ }^{2}$ Public Service Commission (2009).

${ }^{3}$ In Gregg v. Georgia 428 U.S. 153, 96 S.Ct. 2909, L.Ed. 2d. 859 (1976) the Court as per Brennan $\mathrm{J}$ in a dissenting judgment observed as follows: "The fatal constitutional infirmity in the punishment of death is that it treats "members of the human race as nonhumans, as objects to be toyed with and discarded. [It is] thus inconsistent with the fundamental premise of the Clause that even the vilest criminal remains a human being possessed of common human dignity"(Emphasis added)

${ }^{4}$ [1993] 2 SCR at 438
} 
punished as the government sees fit, even to the point of removing fundamental constitutional rights (Emphasis added). Yet, the right to punish and to denounce, however important, is constitutionally constrained. It cannot be used to write entire rights out of the Constitution, it cannot be arbitrary, and it must serve the constitutionally recognised goal of sentencing."

The above mentioned view is bolstered by Corbett ${ }^{1} \mathrm{JA}^{\prime}$ 's expression:

"[f]undamentally a convicted and sentenced prisoner retains all the basic rights and liberties (using the word in its Hohfeldian sense ) of an ordinary citizen except those taken away from him by law expressly or by implication, or those necessarily inconsistent with the circumstances in which he, as a prisoner, is placed."

\section{Constitutional Protection}

Since the dawn of the new constitutional dispensation, South Africa is a member of the international community and as such must conduct itself with the prescripts of international society. First and foremost the Constitution guarantees every citizen the right to choose their trade, occupation or profession freely, although such trade, occupation or profession may be regulated by law. ${ }^{2}$ People must be in a position to freely partake in the economic and political affairs of their own country and thus to earn a living. The lack of earning capacity has disastrous consequences for ex-convicts notwithstanding the fact that they have a constitutional right to dignity. ${ }^{3}$ The lack of employment can have serious repercussions on the dignity of an individual.

The impairment of the right to dignity by discrimination has been summarised by the Constitutional court in Harksen $v$ Lane NO and Others ${ }^{4}$ as follows:

"Discrimination denotes the potential to impair the fundamental dignity of persons as human beings or to affect them adversely in a comparably serious manner"

The right to dignity is amongst the most important of fundamental rights yet undermined in its application; however, this right has been treated like any other right. In actual fact the right to dignity has been elevated by the

\footnotetext{
${ }^{1}$ Goldberg and others $v$ Minister of Prisons 1979 (1) SA 14 (A) at 39.

${ }^{2} \mathrm{~S} 22$

${ }^{3}$ McGregor et al (2014) 105.

${ }^{4} 1998$ (1) SA 300 (CC) at 47
} 
Constitutional court in $S v$ Makwanyane ${ }^{1}$ where this right to dignity reigned supreme over the state's right to death sentence.

South Africa has international obligations under binding treaties and customary international law in the field of human rights which promote equality and prohibit unfair discrimination. There are many international conventions which South Africa is a member of; however, on the $10^{\text {th }}$ of December 1998 two conventions were ratified by South Africa which are the International Convention on the Elimination of All forms of Racial Discrimination and the Convention against Torture and Other Cruel, Inhuman or Degrading Treatment or Punishment. Furthermore the Convention against Discrimination in Education was ratified on 9 March 2000 by South Africa. This is in line with the constitution. Section $231^{2}$ provides as follows;

International agreements.-(1) The negotiating and signing of all international agreements is the responsibility of the national executive. (2) An international agreement binds the Republic only after it has been approved by resolution in both the National Assembly and the National Council of Provinces, unless it is an agreement referred to in subsection (3). (3) An international agreement of a technical, administrative or executive nature, or an agreement which does not require either ratification or accession, entered into by the national executive, binds the Republic without approval by the National Assembly and the National Council of Provinces, but must be tabled in the Assembly and the Council within a reasonable time (4) Any international agreement becomes law in the Republic when it is enacted into law by national legislation; but a selfexecuting provision of an agreement that has been approved by Parliament is law in the Republic unless it is inconsistent with the Constitution or an Act of Parliament. (5) The Republic is bound by international agreements which were binding on the Republic when this Constitution took effect.

Furthermore section $232^{3}$ reads as follows

"Customary international law.-Customary international law is law in the Republic unless it is inconsistent with the Constitution or an Act of Parliament."

Lastly the courts are empowered to take into account any international law when interpreting any legislation. Section $233^{4}$ provides Application of international law. When interpreting any legislation, every court must prefer any reasonable interpretation of the legislation that is consistent with international law over any alternative interpretation that is inconsistent with international law.

\footnotetext{
${ }^{1} 1995$ (2) SACR 1 (CC) at 14, 16, 26

${ }^{2}$ Constitution of Republic of South Africa Act, 1996

${ }^{3}$ Constitution of Republic of South Africa Act, 1996

${ }^{4}$ Constitution of Republic of South Africa Act, 1996
} 
It is also befitting to make mention of the fact that South Africa is a member party to the African Charter on Human and Peoples' Rights. This state of affairs is firmly entrenched in the South African Constitution ${ }^{1}$. Section $234^{2}$ deals with such matter and provides as follows. In order to deepen the culture of democracy established by the Constitution, Parliament may adopt Charters of Rights consistent with the provisions of the Constitution.

\section{Conclusion and Recomendations}

It is only befitting to safely assume that it is highly unfair for people to be judged and to be continued to be punished based on their past deeds or solely on their character. If punishment is continuous then there is no such a thing as rehabilitation and reintegration of ex-convicts. After a critical analysis and consideration of all literature, one concludes as follows. Evidence as explored in this articles points to the very fact that indeed other categories of people like ex-convicts are discriminated against unfairly so and are furthermore denied an opportunity to partake in the labour affairs of their birth country. Whereas on the other hand, others with criminal records are employed and are occupying high profile offices despite their convictions, like the police officials who were publicised for having criminal records and yet remaining in the employ of the government. Having said this one can only recommend and hope that at least such recommendations are well implemented so as to curb the prejudicial effects of previous convictions on ex-convicts.

In light of the prevalence of such discrimination, it is recommended that a furthermore social research be conducted as the focus of this paper was based on literature review. If combination of both qualitative and qualitative methodology in the form of questionnaires and interviews are conducted, then it can be relatively easy to establish magnitude and effects of previous convictions regarding the fitness of ex-convicts to occupy labour mainstreams.

Furthermore it is recommended that the law be reformed in such a way that it meets the constitutional mandate of eliminating and prohibiting all sorts of discrimination thus protecting and promoting fundamental rights of all human beings more specially ex-convicts;. To declare all laws governing previous convictions unconstitutional or alternatively to reduce the ten years period to five years.

To rectify the lacunae which exists relating to the lapse of time of previous convictions as regulated by both the Criminal Procedure Act 51 of 1977 and the Child justice Act 75 of 2008 . There are inconsistencies in as far as the lapse of time is concerned in that it is ten years as prescribed by the Criminal Procedure Act 51 of 1977 and 5 years for child offenders for certain offences as prescribed by the Child Justice Act 75 of 2008.

It is also recommended that too much emphasis be placed on the rehabilitation and reintegration of ex-convicts than to continue punishing them

\footnotetext{
${ }^{1}$ Section 234 Constitution of Republic of South Africa Act, 1996

${ }^{2}$ Constitution of Republic of South Africa Act, 1996
} 
excessively for crimes which they have already sentenced or punished for. This is in line with the objectives, mission and vision of the department of correctional services in general but more in particular the white paper on corrections as adopted by the department of correctional services.

Again it is strongly recommended that there must be a bridging of a gap in the treatment of people in general as per the constitution which provides in section 9 that everyone is equal before the law and has the right to equal protection and the benefit of the law. it can't be that currently there are approximately one thousand four hundred and forty eight police official with criminal records occupying senior ranks in the South African Police Service and till to date are still within the employ of the South African Police Services whereas others are denied such opportunity.

Lastly since South Africa is part of the broader international community and since South African Criminal Justice System is lagging behind, and since similar challenges are faced in other countries who are effectively dealing with such challenge, South Africa must learn from such foreign countries effective solutions of addressing this issue. Furthermore South Africa must conform to international standard.

\section{References}

Chatterton, C. (1984). The sentencing approach. Barry Rose Publishers.

Durham, M, A. (1987). 'Justice in sentencing: the role of prior record of criminal involvement.' J. Crim. L. \& CRIMINOLOGY 78(3): 614-643

Love M, C. (2002). 'Starting over with a clean slate: In Praise of a forgotten section of the model penal code.' Fordham URB. L.J 30 (5): 1705-1741

McGregor, M. Dekker, A. Budeli-Nemakonde, M. Germishuys, W. Manamela, E. Manamela, T. \& Tshoose, C. (2014). Labour Law Rules. $2^{\text {nd }}$ ed. Siber Ink.

Muntingh, L. (2005). 'Offender rehabilitation and reintegration: taking the white paper on corrections forward. 'Civil Society Prison Reform Initiative 10: 1-46.

Muntingh, L. (2011). 'The law and the business of criminal record expungement in South Africa.' Civil Society Prison Reform Initiative 18: 1-30.

Naude, B. (2002). 'Legislative expungement of criminal records.' SACJ 15: 287,

Public Service Commission (2009). Management of job applicant with a criminal record in the public service. SA: PSC.

Slabbert, M. (2011). 'The requirement of being a "fit and proper" person for the legal profession.' P.E.R 14 (4): 209-239.

Snyman CR, Criminal Law. (2008). $5^{\text {th }}$ ed. LexisNexus Durban.

Von Hirsch, A \& Ashworth, A. (eds). (2005). Proportionate sentencing: Exploring the principles. Oxford University Press.

\section{Cases}

Du plessis v Department of Correctional Services PSGA 787-05/06.

Gregg v. Georgia 428 U.S. 153, 96 S.Ct. 2009, LEd. 2d. 859 (1976).

Goldbergand Others v Minister of Prisons 1979 (1) SA 14 (A). 
Harksen v Lane NO and Others 1998 (1) SA 300 (CC).

In Re Ngwenya v Society of Advocates, Pretoria and Another 2006 (2) SA 87 (W).

Masenya v Fidelity springbok Services GAJB 33462-05.

Prince v President, Cape Law Society 2002 (2) SA 794 (CC).

Sauve v Canada (Chief Electoral officer) [1993] 2 SCR.

S v Makwanyane 1995 (2) SACR 1 (CC).

$\mathrm{R}$ (on the applications of $\mathrm{P}$ and A) v Secretary of State for Justice \& Ors [2016] EWHC 89 (Admin); R (L) v Commissioner for the Metropolis [2010] 1 AC 410. [2014] UKSC 35 (On appeal from: [2013] EWCA Civ 25)

\section{Legislation}

Constitution of Republic of South Africa Act, of 1996.

Attorneys Act 53 of 1979.

Employment Equity Act 55 of 1998.

Employment of Educators Act 76 of 1998.

National Strategic Intelligence Amendment Act 67 of 2002.

South African Police Service Act 68 of 1995.

Public Service Act 103 of 1994.

Proclamation R 1599 Government Gazette 24194 of 27 December 2002.

Promotion of Equality and Prevention of Unfair discrimination Act 4 of 2000

Rehabilitation of Offenders Act 1974

\section{Internet sources}

http://mybroadband.co.za/vb/showthread.php/50068-DA-rejects-scrapping-of-crimina l-records (accessed 05/05/2014)

Correction Service "White Paper Discusion of 2005 as found in http://www.dcs.gov .za/AboutUs/COE/whitepaper.aspx (accessed 05/05/2014)

http://www.news24.com/SouthAfrica/News/1-448-cops-have-criminal-records-20130 $\underline{814}$ (accessed 06/05/2014)

http://www.timeslive.co.za/thetimes/2013/06/14/captain-kgb---witnesses-in-peril (accessed 09/0512014)

News 24 2014-06-01 http://www.news24.com/SouthAfrica/News/NPA-boss-claimsthere-is-a-plot-to-oust-him-20140601 (accessed 03/06/2014)

http://metro.co.uk/2013/01/29/disclosing-previous-convictions-to-employers-humanrights-breach-court-rules-3371483/ (accessed 07/04/2014) 
